\title{
Efficacy and safety of lamivudine treatment in late pregnancy with high HBV DNA: a perspective for mother and infants
}

\author{
Şükran Köse ${ }^{1}$, Melda Türken ${ }^{1}$, İlker Devrim²${ }^{2}$, Cüneyt Taner ${ }^{3}$ \\ ${ }^{1}$ Tepecik Training and Research Hospital, Department of Infectious Diseases and Clinic Microbiology, Turkey \\ ${ }^{2}$ Republic of Turkey Ministry of Health, Dr. Behcet Uz Children's Training and Research Hospital, Department of \\ Pediatric Infectious Diseases \\ ${ }^{3}$ Izmir Aegean Obstetrics and Gynecology Teaching Hospital, Izmir, Turkey
}

\begin{abstract}
Introduction: Perinatal transmission - from mother to fetus - is one of the main transmission routes of chronic hepatitis B (CHB) infection. Lamivudine therapy has been reported to prevent the replication of hepatitis B virus (HBV) in pregnant women with a high viral load that can lead to perinatal transmission.

Methodology: This study sought to evaluate retrospectively the efficacy and safety of lamivudine treatment in pregnant women with CHB and a high viral load. Biochemical parameters, and virological and serological responses at the $32^{\text {nd }}$ and $36^{\text {th }}$ week of gestation and after labor were recorded. The complications of CHB and the adverse effects of lamivudine treatment were also recorded.

Results: Following 8 weeks of lamivudine treatment, HBV viral load decreased to levels $\leq 10,000$ copies/ml in five of the seven patients $(71 \%)$ and in three patients (43\%), HBV DNA was found to be completely negative after labor. Neither adverse effects caused by lamivudine treatment nor complications due to CHB infection were experienced by mothers or infants.

Conclusions: The results of this study suggest that lamivudine therapy in highly viremic hepatitis B surface antigen (HBsAg)-positive pregnant women could decrease perinatal transmission rates of $\mathrm{HBV}$, and can lower the HBV viral load during labor.
\end{abstract}

Key words: lamivudine; chronic hepatitis B infection; pregnancy

J Infect Dev Ctries 2011; 5(4):303-306.

(Received 16 July 2010 - Accepted 09 October 2010)

Copyright (C) 2011 Kose et al. This is an open-access article distributed under the Creative Commons Attribution License, which permits unrestricted use, distribution, and reproduction in any medium, provided the original work is properly cited.

\section{Introduction}

Perinatal transmission - from mother to fetus - is one of the main causes of transmission of chronic hepatitis B (CHB) infection [1]. Passive immunization with hepatitis B immune serum globulin (HBIg) plus active immunization with a hepatitis B vaccine at birth, the first and the sixth month of life is required to prevent transmission [2]. The presentation of antigenemia in the baby between six weeks and six months after birth demonstrates that HBV can be transmitted during labor, or after labor through breastfeeding [3].

The risk of transmission from $\mathrm{HBV}$-infected mothers to newborns is $10-40 \%$ in hepatitis B "e" antigen ( $\mathrm{HBeAg}$ ) negative mothers and $90 \%$ in HBeAg-positive mothers [4]. Approximately 85-95\% of infected infants will become chronic HBV carriers $[5,6]$. The risk of transmission has been reported to be high from mothers with high HBV DNA copies in circulation [7,8]. Nucleoside analogs have been effective in preventing the transmission of HIV-1 in pregnancies, and lamivudine was found to be safe in HIV and HBV co-infected mothers when used in the last weeks of the third trimester $[9,10]$. Further studies reported that lamivudine therapy prevented the replication of HBV in pregnant women with a high viral load $[1,11,12]$.

This study aimed to evaluate retrospectively the efficacy and safety of lamivudine treatment in pregnant women with $\mathrm{CHB}$ and high viral loads when given during the last trimester.

\section{Methodology}

Seven pregnant patients with CHB who were admitted to the infectious diseases and clinical microbiology and obstetrics clinics between January and May 2009 were evaluated retrospectively. HBsAg, anti-HBs, HBeAg, and anti-HBe levels were measured with the Micro ELISA (Liason, Diasorin, Italy). HBV DNA viral load was 
Table 1. The demographic features, initial viral load and ALT levels, and responses to therapy by means of ALT levels and viral load.

\begin{tabular}{|c|c|c|c|c|c|c|c|c|c|c|}
\hline Patient & Age & $\begin{array}{l}\mathrm{HBe} \\
\mathrm{Ag}\end{array}$ & $\begin{array}{l}\text { Previous } \\
\text { treatment }\end{array}$ & $\begin{array}{l}\text { Lamivudine } \\
\text { resistance }\end{array}$ & $\begin{array}{l}\text { Initial } \\
\text { ALT level } \\
(\mathrm{UI} / \mathrm{l})\end{array}$ & $\begin{array}{l}\text { HBV Viral } \\
\text { load } \\
\text { (copies/ml) }\end{array}$ & $\begin{array}{l}\text { ALT level at } \\
\text { the 36th } \\
\text { gestational } \\
\text { week }\end{array}$ & $\begin{array}{l}\text { HBV Viral } \\
\text { load at the } \\
\text { 36th week }\end{array}$ & $\begin{array}{l}\text { ALT } \\
\text { level after } \\
\text { birth (8th } \\
\text { week of } \\
\text { therapy) }\end{array}$ & $\begin{array}{l}\text { HBV Viral } \\
\text { load after } \\
\text { birth (8th } \\
\text { week of } \\
\text { therapy }\end{array}$ \\
\hline I & 33 & - & naive & - & 25 & $1.05 \times 10^{5}$ & 24 & $2.3 \times 10^{4}$ & 23 & $1.07 \times 10^{3}$ \\
\hline II & 23 & + & naive & - & 24 & $1 \times 10^{8}$ & 20 & $1.26 \times 10^{6}$ & 18 & $1.03 \times 10^{4}$ \\
\hline III & 26 & - & naive & - & 21 & $1.88 \times 10^{4}$ & 20 & negative & 18 & negative \\
\hline IV & 26 & - & IFN & - & 62 & $4.4 \times 10^{5}$ & 48 & negative & 42 & negative \\
\hline V & 30 & + & $\begin{array}{l}\text { IFN,LAM,A } \\
\text { DV }\end{array}$ & + & 44 & $1 \times 10^{8}$ & 45 & $1 \times 10^{8}$ & 25 & $1 \times 10^{8}$ \\
\hline VI & 27 & - & peg IFN & - & 74 & $3 \times 10^{6}$ & 28 & negative & 26 & negative \\
\hline VII & 21 & + & peg IFN & - & 42 & $1 \times 10^{8}$ & 36 & $3.65 \times 10^{3}$ & 13 & $1.88 \times 10^{2}$ \\
\hline
\end{tabular}

measured by real time PCR (PCR COBAS AmpliPrep/COBAS TaqMan 48, Roche, Branchburg, NJ). Periodic liver function tests were conducted on all patients monthly.

None of the patients had a history of antiviral drug treatment before the $32^{\text {nd }}$ gestational week of pregnancy. Lamivudine resistance was determined using the reverse hybridization technique as previously described [13]. Co-infections such as HIV, HCV and HDV were ruled out through specific serological tests.

Lamivudine (100 $\mathrm{mg} /$ day) therapy was given to seven pregnant patients with CHB who had levels of HBV DNA greater than 10,000 copies/ml after the thirty-second gestational week. Biochemical parameters, virological and serological responses both at the $32^{\text {nd }}$ and $36^{\text {th }}$ week of gestation, and after labor were recorded. The complications of CHB and adverse effects of lamivudine treatment were also recorded.

\section{Results}

The mean age of the pregnant women was 26.5 years \pm 4.0 (ranging from 21 to 33 years of age). Among seven patients, three $(43 \%)$ were $\mathrm{HBeAg}$ positive. The mean serum alanine aminotransferase (ALT) level was $41.7 \pm 20.3$ (ranging from 21 to 74 $\mathrm{IU} / \mathrm{ml}$ ) and the median HBV DNA viral load was 3.0 x $10^{6}$ copies $/ \mathrm{ml}$. A total of four patients had a history of previous interferon usage, and one patient was treated with lamivudine and adefovir before pregnancy. Lamivudine resistance was detected in the latter patient and although the ALT levels of this patient returned to normal, the HBV viral load did not decrease.
In the $36^{\text {th }}$ week of gestation, during the fourth week of treatment, $100 \%$ of the patients' ALT levels had returned to normal range. A $10^{2}$ decrease in $\mathrm{HBV}$ viral load was observed in $71 \%(5 / 7)$ of the patients and HBV DNA became entirely absent in three patients $(43 \%)$.

After labor, during the eighth week of treatment, the serum ALT levels of treated patients remained normal. Two patients whose viral load of HBV did not fall below levels of 10,000 copies $/ \mathrm{ml}$ were HbeAg-positive and one had documented lamivudine resistance. Among the three $\mathrm{HBeAg}$-positive patients, none showed seroconversion, while only one of these patients had a virological response.

No adverse effects caused by lamivudine and complications due to $\mathrm{CHB}$ infection were experienced during this period. The demographic features, initial viral load, ALT levels and responses to therapy by means of ALT levels and viral load are reviewed in Table 1.

No unfavorable outcomes related to the newborns' health during the first six months of age were detected by pediatricians. Birth weights, birth weeks and $\mathrm{HbsAg} / \mathrm{Anti}-\mathrm{HbsAg}$ statuses are summarized in Table 2. No seroconversion of HbsAg was observed in any patient.

\section{Discussion}

No serious or hazardous effect on conception and pregnancy has been documented in women with CHB. Following vertical transmission of HBV during labor or pregnancy, the likelihood of chronic disease developing in infants exceeds $90 \%$, which indicates 
Table 2. Demographic features of the newborns and their HBsAg/anti-HBsAg statuses

\begin{tabular}{|l|l|l|l|l|l|}
\hline $\begin{array}{l}\text { Patient/ } \\
\text { newborn }\end{array}$ & Labor & $\begin{array}{l}\text { Gestational } \\
\text { Week }\end{array}$ & $\begin{array}{l}\text { Birth } \\
\text { Weight } \\
\text { (grams) }\end{array}$ & $\begin{array}{l}\text { HBsAg } \\
\text { status at 6th } \\
\text { week }\end{array}$ & $\begin{array}{l}\text { Anti-HBsAg } \\
\text { status at 6th } \\
\text { week }\end{array}$ \\
\hline I & C/S & 39 & 3600 & - & + \\
\hline II & C/S & 40 & 3900 & - & + \\
\hline III & NSVD & 38 & 3400 & - & + \\
\hline IV & NSVD & 38 & 3100 & - & + \\
\hline V & C/S & 36 & 2850 & - & + \\
\hline VI & NSVD & 40 & 3500 & - & + \\
\hline VII & NSVD & 40 & 3500 & - & + \\
\hline C/S, Cesarean section; NSVD, normal spontaneous vaginal
\end{tabular}

that it is a health care problem [14]. One study suggested chorion angiopathy and fetal distress syndrome as potential outcomes [15].

During pregnancies in which the mother has a high viral load of HBV, antiviral therapy during the third trimester could decrease the probability of vertical transmission. Lamivudine was reported to be effective in acute attacks of HBV infection during the third trimester [16]. No congenital anomaly was reported in neonates whose HIV-positive mothers were treated with antiviral therapy including lamivudine [9]. A study from China, where HBV infection was endemic, reported that lamivudine therapy prevented both vertical transmission and the reactivation of $\mathrm{HBV}$ infection in pregnant patients with CHB [12].

Nucloeoside reverse transcriptase inhibitors (NRTI) were found not to be teratogenic in animals when the dosage levels given to humans were administered. The L-form enantiomer of lamivudine, its non-selective form, showed toxic effects when 1,000 times the normal dosage was exceeded (11). The suggested dose of lamivudine was reported to have a low risk in pregnancies [11,17]. NRTIs bind to mitochondrial DNA polymerase gamma and result in myopathy, lactic acidosis and a fatty liver. However, prolonged therapy in pregnancy could result in toxic effects [18]. In the present study, no prominent adverse effects or complications caused by lamivudine therapy were observed in either mothers or infants.

In the current study, lamivudine was found to be effective in lowering HBV DNA in $71 \%$ of the patients and preventing $\mathrm{HBsAg}$ seropositivity in infants. In another study, infants of lamivudinetreated mothers (who had received HBIg and a vaccine) were reported to have a significant decrease in incidence of $\mathrm{HBsAg}$ seropositivity compared to a control group who had only received HBIg and a vaccine [12]. In another study, lamivudine was reported to lower HBV DNA levels in pregnant patients with a high viral DNA load, thus reducing perinatal transmission [14]. In the current study, no adverse effects caused by lamivudine therapy were observed in mothers or infants, supporting previous studies.

Emerging resistance is the major limitation of lamivudine usage and is generally associated with the YMDD motif of the HBV polymerase gene [16]. In the present study, only one patient had lamivudine resistance, but this patient's HBV DNA did not increase during lamivudine treatment. This result was supported by a previous report suggesting re-use of lamivudine was effective in exacerbation of $\mathrm{CHB}$ during pregnancy [19].

In conclusion, the results of this study suggest that lamivudine therapy in highly viremic HBsAgpositive pregnant women could lower perinatal transmission rates of $\mathrm{HBV}$ and lower the $\mathrm{HBV}$ viral load during of labour. Development of resistance to lamivudine is a potential risk; therefore, further largescale, double-blind studies are required.

\section{References}

1. Van Nunen AB, de Man RA, Heijtink RA, Niesters HG, Schalm SW (2000) Lamivudine in the last 4 weeks of pregnancy to prevent perinatal transmission in highly viremic chronic hepatitis B patients. J Hepatol 32: 10401041.

2. Seef LB and Koff RS (1984) Passive and active immunoprophylaxis of hepatitis B. Gastroenterology 86: 958-981.

3. World Health Organization (1998) Hepatitis B and breastfeeding. J Int Assoc Physicians AIDS Care 4: 20-21.

4. Okada K, Kamiyama I, Inomata M, Imai M, Miyakawa Y, Mayumi M (1976) E antigen and anti e in the serum of asymptomatic carrier mothers as indicators of positive and negative transmission of hepatitis $\mathrm{B}$ virus to their infants. $\mathrm{N}$ Engl J Med 294: 746-749.

5. Stevens CE, Beasley RP, Tsui J, Lee WC (1975) Vertical transmission of hepatitis B antigen in Taiwan. N Engl J Med 292: 771-774 
6. Stevens CE, Toy PT, Tong MJ, Taylor PE, Vyas GN, Nair PV, Gudavalli M, Krugman S (1985) Perinatal hepatitis B virus transmission in the United States: prevention by passive-active immunization. JAMA 253: 1740-1745.

7. Del Canho R, Grosheide PM, Mazel JA, Heijtink RA, Hop WCJ, Gerards LJ, de Gast GC, Fetter WPF, Zwijneberg J, Schalm SW (1997) Ten-year neonatal hepatitis B vaccination program, The Netherlands, 1982-1992: Protective efficacy and long-term immunogenicity. Vaccine 15: 1624-1630.

8. Ip HM, Wong VCW, Lelie PN, Kuhns MC, Reesink HW (1989) Prevention of hepatitis B virus carrier state in infants according to maternal serum levels of HBV DNA. Lancet 1 : 406-410.

9. Faucher P, Batallan A, Bastian H, Matheron S, Morau G, Madelenat P, Benifla JL (2001) Management of pregnant women with HIV at Bichat Hospital between 1990 and 1998: analysis of 202 pregnancies. Gynecol Obstet Fertil 29: 211-225.

10. Moodley J, Moodley D, Pillay K, Coovadia H, Saba J, van Leeuwen R, Goodwin C, Harrigan PR, Moore KH, Stone C, Plumb R, Johnson MA (1998) Pharmacokinetics and antiretroviral activity of lamivudine alone or when coadministered with zidovudine in human immunodeficiency virus type 1-infected pregnant women and their offspring. J Infect Dis 178: 1327-1333.

11. Johnson MA, Moore KHP, Yuen GJ, Bye A, Pakes GE (1999) Clinical pharmacokinetics of lamivudine. Clin Pharmacokinet 36: 41-66.

12. Xu WM, Cui YT, Wang L, Yang H, Liang ZQ, Li XM, Zhang SL, Qiao FY, Campbell F, Chang CN, Gardner S, Atkins M (2009) Lamivudine in late pregnancy to prevent perinatal transmission of hepatitis $\mathrm{B}$ virus infection: a multicentre, randomized, double-blind, placebo-controlled study. J Viral Hepat 16: 94-103.

13. Akman SA, Kose S, Halicioglu O. (2010). Lamivudine and adefovir resistance in children and young adults with chronic hepatitis B. Int J Infect Dis 14: e236-9.
14. Van Zonneveld M, van Nunen AB, Niesters HG, de Man RA, Schalm SW, Janssen HL (2003) Lamivudine treatment during pregnancy to prevent perinatal transmission of hepatitis B virus infection. J Viral Hepat 10: 294-297

15. Yang H, Chen R, Li Z, Zhou G, Zhao Y, Cui D, Li S, Han C, Yang L (2002) Analysis of fetal distress in pregnancy with hepatitis B virus infection. Zhonghua Fu Chan Ke Za Zhi 37: 211-213.

16. Xu XW and Chen YG (2006) Current therapy with nucleoside/nucleotide analogs for patients with chronic hepatitis B. Hepatobiliary Pancreat Dis Int 5: 350-359.

17. Su GG, Pan KH, Zhao NF, Fang SH, Yang DH, Zhou Y (2004) Efficacy and safety of lamivudine treatment for chronic hepatitis B in pregnancy. World J Gastroenterol 10: 910-912.

18. Deverbhavi H, Kremers WK, Dierkhising R, Padmanabhan L (2008) Pregnancy-associated acute liver disease and acute viral hepatitis: Differentiation, course and outcome. J Hepatol 49: 930-935.

19. Hung JH, Chu CJ, Sung PL, Chen CY, Chao KC, Yang MJ, Hung SC (2008) Lamivudine therapy in the treatment of chronic hepatitis B with acute exacerbation during pregnancy. J Chin Med Assoc 71: 155-158.

\section{Corresponding author}

Sukran Köse

Department of Infectious Diseases and Clinic Microbiology Department of Infectious Tepecik Training and Research Hospital

İzmir, Turkey

Telephone: 905323410545

Fax numbers: 902324892315

Email: sukrankose@yahoo.com

Conflict of interests: No conflict of interests is declared. 